Original Research Paper

\title{
Sosialisasi Perilaku Hidup Bersih dan Sehat (PHBS) di Tempat Kerja Sebagai Upaya Pencegahan Penularan Covid 19
}

\author{
Aini $^{1}$, Made Sriasih 2 \\ ${ }^{1}$ Program Studi DIII Teknologi Laboratorium Medis Politeknik Medica Farma Husada Mataram \\ ${ }^{2}$ Magister Manajemen Sumber Daya Peternakan Universitas Mataram
}

DOI: $10.29303 /$ jpmpi.v3i1.466

Sitasi:. Aini., \& Sriasih, M. (2020). Sosialisasi Perilaku Hidup Bersih dan Sehat (PHBS) di Tempat Kerja Sebagai Upaya Pencegahan Penularan Covid 19. Jurnal Pengabdian Magister Pendidikan IPA, 3(2)

\author{
Article history \\ Received: 28 Oktober 2020 \\ Revised: 10 Nopember 2020 \\ Accepted: 27 Nopemeber 2020 \\ *Corresponding Author: \\ Aini, \\ Program Studi DIII Teknologi \\ Laboratorium Medis Politeknik \\ Medica Farma Husada \\ Mataram, Universitas Mataram, \\ Indonesia; \\ Email: ainie.mfh@gmail.com
}

\begin{abstract}
Abstrak: Pemerintah provinsi NTB pada bulan Maret 2020 menyatakan bahwa penyebaran virus Corona telah sampai ke wilayah NTB. Salah satu upaya dalam pencegahan penyebaran virus Corona masuk ke dalam tubuh kita adalah dengan menjaga kebersihan diri dengan menerapkan Perilaku Hidup Bersih dan Sehat (PHBS) dan dengan mencuci tangan dengan baik menggunakan sabun maupun cairan antiseptik. Praktik PHBS terutama di tempat kerja yang melibatkan banyak orang berkumpul sangat perlu untuk diterapkan. Tujuan dari pengabdian ini adalah untuk membentuk pemahaman masyarakat terutama para karyawan di tempat kerja yaitu di PT. Narmada Awet Muda sebagai salah satu industri Air Minum Dalam Kemasan (AMDK) terhadap penyebaran virus dan pencegahannya terutama virus Corona. Kegiatan pengabdian dilakukan dengan metoda ceramah, diskusi serta demonstrasi dan diikuti oleh sekitar 200 karyawan pabrik PT. Narmada Awet Muda. Hasil kegiatan pengabdian menunjukkan bahwa tingkat pengetahuan dan pemahaman karyawan meningkat $(80.8 \%)$ terhadap PHBS dan cara cuci tangan yang baik sebagai upaya pencegahan penularan virus Corona.
\end{abstract}

Kata kunci: Pengetahuan, Virus Corona, Cuci tangan, Pabrik, Nusa Tenggara Barat

dimulai dari diri sendiri untuk menciptakan sumber daya manusia (SDM) yang produktif. Ada beberapa tatanan PHBS yaitu di rumah tangga sekolah, tempat kerja, sarana kesehatan dan tempat umum (Anonim, 2011)

World Health Organization (WHO) pada Maret 2020 menetapkan Corona Virus-19 (Covid19) sebagai pandemi (WHO, 2020). Provinsi Nusa Tenggara Barat (NTB) mengumumkan adanya kasus Covid pertama pada Maret 2020 (BNPB, 2020a). Sebagai bentuk preventif terhadap adanya Covid saat ini pemerintah meminta masyarakat untuk mengikuti protokol kesehatan untuk mencegah penyebaran virus Corona.

PT. Narmada Awet Muda sebagai salah satu salah satu industri Air Minum Dalam Kemasan (AMDK) merupakan pabrik yang melakukan 
aktivitas produksi dengan melibatkan banyak karyawan. Pabrik ini membutuhkan sosialisasi untuk seluruh karyawan akan pentingnya PHBS dalam proses produksi. Selain menerapkan proses Good Manupacturing Practice (GMP) industri juga wajib menerapkan berbagai protokol kesehatan dasar untuk mencegah terjadinya penularan pada karyawan yang dapat memberikan dampak terhadap seluruh proses produksi. Salah satu cara yang wajib dilakukan untuk memberikan pemahaman terhadap seluruh karyawan adalah dengan memberikan edukasi kepada seluruh karyawan/karyawati staff tentang PHBS dan cara cuci tangan yang baik sebagai salah satu usaha untuk mengajak seluruh karyawan dalam memutus penyebaran virus Corona.

Upaya dalam pencegahan penyebaran virus Corona masuk kedalam tubuh adalah dengan menjaga kebersihan diri salah satunya dengan menerapkan PHBS dan dengan mencuci tangan dengan baik menggunakan sabun maupun cairan antiseptik. Cara lainnya adalah dengan meminimalisir menyentuh area wajah jika tangan masih kotor, menggunakan masker serta menjaga jarak fisik/ phycical distancing (BNPB, 2020b). Usaha untuk mencegah penyebaran virus Corona ini perlu dilakukan melalui suatu kegiatan untuk mengajak seluruh karyawan terutama industri yang sulit untuk melakukan pembatasan jumlah karyawan untuk menerapkan PHBS (BNPB, 2020a).

Kendala awal yang dihadapi oleh PT. Narmada Awet Muda pada saat pandemi ini adalah kurangnya pemahaman karyawan terhadap virus, cara pencegahan, protokol kesehatan yang harus diterapkan agar proses produksi dapat berjalan. Oleh karena itu diperlukan suatu usaha untuk memberikan pemahaman mengapa harus mencuci tangan dan mengikuti protokol kesehatan.

Pemerintah mengeluarkan program PHBS pada tahun 2015 akan tetapi program ini pada awalnya sering diabaikan dan dianggap hanya jargon. Adanya pandemi ini dengan edukasi yang dilakukan diharapkan membentuk pemahaman masyarakat terutama para karyawan di tempat kerja terhadap penyebaran virus dan pencegahannya terutama virus Corona.

\section{Metode}

Kegiatan pengabdian masyarakat ini dilakukan dengan metode ceramah dan diskusi kepada seluruh karyawan. Setelah pemberian materi melalui ceramah dan diskusi kegiatan dilanjutkan dengan praktik atau demostrasi cara cuci tangan yang baik. Kegiatan ini dilaksanakan pada hari Kamis, 26 Maret 2020.

1. Ceramah

Metode ceramah digunakan untuk menyampaikan materi dengan rinci. Topik yang disampaikan antara lain
a. Virus corona (karakteristik, cara penularan, cara pencegahan)
b. PHBS dan cara cuci tangan yang baik cara cuci tangan yang baik.

2. Diskusi

Metode diskusi digunakan untuk mengakomodir pertanyaan dan masukan dari materi yang disampaikan.

3. Praktik

Metode praktik digunakan untuk memberikan demonstrasi melalui video tentang virus Corona dan PHBS yang disampaikan oleh pemateri. Demostrasi ini dilakukan agar karyawan tidak hanya sekedar mengetahui tetapi tahu cara melakukannya dengan benar dan baik untuk mencegah penyebaran virus di area pabrik.

4. Evaluasi

Kegiatan ini dilakukan untuk mengetahui tingkat pemahaman peserta kegiatan pengabdian terhadap materi dan praktik yang telah dilakukan. Rincian pelaksanaan kegiatan pengabdian disajikan pada Tabel 1 .

Tabel 1. Rincian dan Materi Kegiatan

\begin{tabular}{|c|c|c|c|}
\hline No. & $\begin{array}{c}\text { Materi } \\
\text { kegiatan }\end{array}$ & Penyaji & Waktu \\
\hline 1. & \begin{tabular}{|l|}
\multicolumn{2}{|l|}{ Penjelasan } \\
tentang virus \\
Corona,
\end{tabular} & $\begin{array}{l}\text { Dr Made } \\
\text { Sriasih }\end{array}$ & $\begin{array}{l}10.00 \quad- \\
11.00\end{array}$ \\
\hline 2 & $\begin{array}{l}\text { Penjelasan } \\
\text { tentang PHBS }\end{array}$ & Aini, M.Si & $\begin{array}{l}11.00- \\
12.00\end{array}$ \\
\hline 2. & Diskusi & Pemateri & $\begin{array}{ll}12.00 & - \\
13.30 & \end{array}$ \\
\hline 3. & $\begin{array}{l}\text { Praktik Cara } \\
\text { cuci tangan }\end{array}$ & Tim & $\begin{array}{l}13.30- \\
14.00\end{array}$ \\
\hline
\end{tabular}




\section{Hasil dan Pembahasan}

PT. Narmada Awet Muda memiliki karyawan seperti sopir dan bagian lain yang melakukan perjalan keluar daerah yang memiliki dampak untuk membawa virus Corona ke area pabrik. Sehingga perlu dilakukan edukasi agar karyawan paham manfaat dalam menerapkan PHBS dan cuci tangan yang baik di lingkungan kerja maupun rumah tangga.

Untuk menciptakan lingkungan kerja yang sehat dan untuk memutus penyebaran dari virus Corona PT. Narmada Awet Muda menghimbau dan memastikan seluruh karyawan untuk menerapkan PHBS dan cuci tangan sesering mungkin dengan cara yang baik (Tirto, 2020). Kegiatan Pengabdian ini dilakukan dengan memberikan edukasi kepada seluruh karyawan tentang, virus corona, cara penularan virus Corona dan cara penularanya, caracara menerapkan PHBS dan mempraktikan cara cuci tangan yang baik dan benar (Gambar 1). Permatasari dkk. (2019) menyatakan bahwa masih terdapat beberapa karyawan yang belum paham cara menerapkan PHBS dan cuci tangan yang benar yang dapat dilihat pada saat karyawan diminta untuk mempraktikan cara cuci tangan. Hasil evaluasi sebelum memulai kegiatan pengabdian di PT. Narmada Awet Muda menunjukkan bahwa hanya sekitar $10.2 \%$ karyawan terutama karyawan di area pengolahan yang melakukan cuci tangan sesuai aturan dalam GMP. Kurangnya pemahaman mengenai manfaat PHBS dan bahaya dari inilah yang membuat banyak karyawan yang mengabaikan kebiasaan cuci tangan yang baik dan benar.

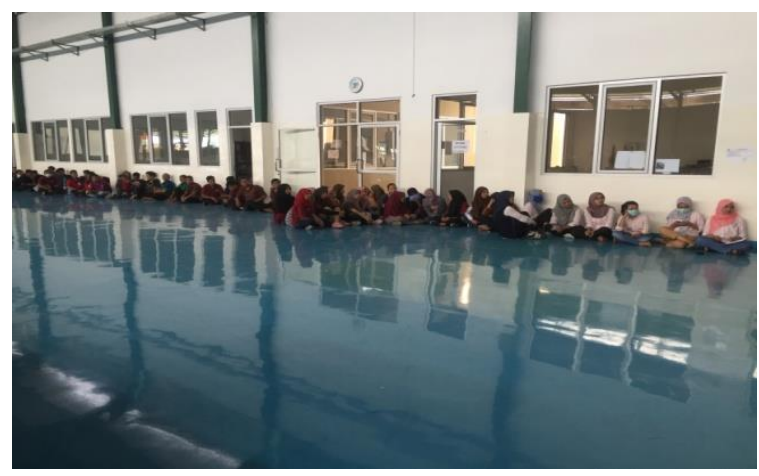

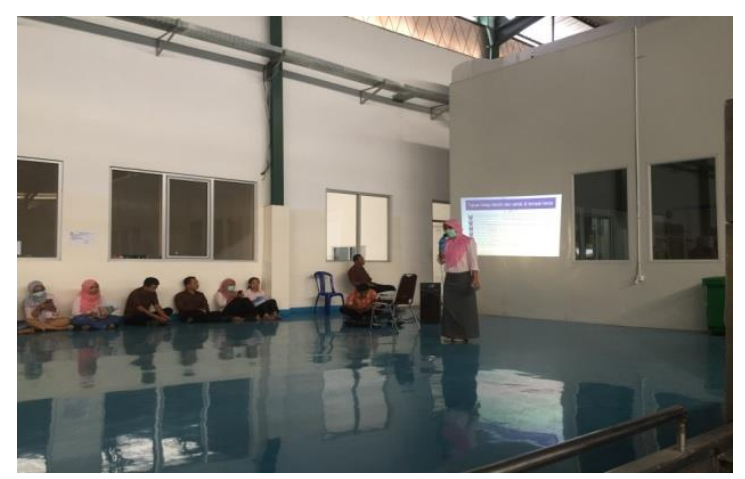

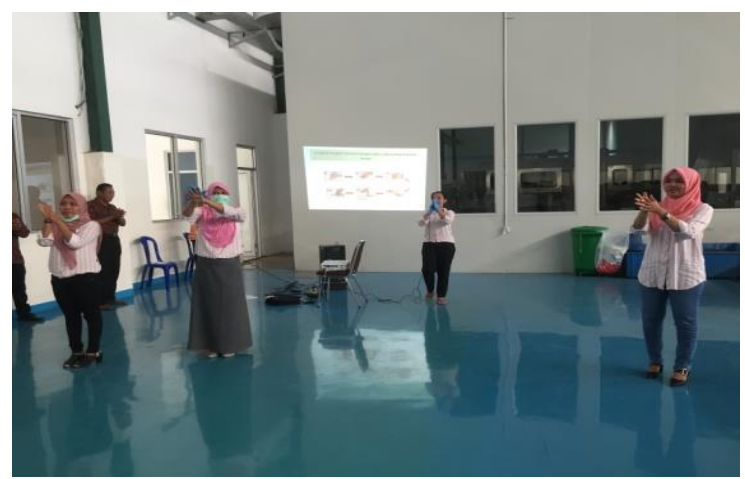

Gambar 1 Penyampaian tentang PHBS dan Cara cuci tangan dengan benar

Kegiatan ini menekankan pentingnya para karyawan untuk menerapkan PHBS dan cuci tangan sesering mungkin. Sebelum memasuki area pabrik karyawan wajib mencuci tangan dengan menggunakan sabun atau handsanitizer, serta pengunaan masker untuk mencegah penyeberan virus Corona di area pabrik. Kegiatan pengabdian yang melibatkan seluruh karyawan dan staf PT. Narmada Awet berjalan dengan baik. Hal ini dapat dilihat dari respon peserta dalam kegiatan ini serta hasil evaluasi setelah kegiatan. Hasil evaluasi menunjukkan bahwa tingkat pengeahuan dan pemahaman karyawan meningkat sebesar $80.8 \%$. Selain meningkatkan pengetahuan dan pemahaman peserta, manfaat lain dari kegiatan pengabdian ini membangun kesadaran seluruh karyawandan staff dalam menjaga kebersihan diri dan kebersihan lingkungan sekitar.

\section{Kesimpulan}

Tingkat pengetahuan dan pemahaman karyawan terhadap PHBS dalam upaya pencegahan Covid-19 di tempat kerja meningkat sebesar 80.8\% dengan adanya kegiatan pengabdian ini. Kegiatan ini diharapkan tetap dilakukan untuk memberikan 
edukasi kepada masyarakat untuk menghindari penyebaran penyakit.

\section{Ucapan Terimakasih}

Tim menyampaikan ucapan terima kasih kepada manajemen PT. Narmada Awet Muda, LPPM Universitas Mataram dan LPPM Politeknik yang telah memberikan dukungan hingga terlaksananya pengabdian ini.

\section{Daftar Pustaka}

Anonim. (2011). Peraturan Menteri Kesehatan Republik Indonesia. Peraturan Menteri Kesehatan No. 2406 TAHUN 2011 Tentang Pedoman Umum Penggunaan Antibiotik, 4.

BNPB. (2020a). https://bnpb.go.id/berita/edukasiberbasis-keluarga-tularkan-kebiasaan-barucegah-covid19.

BNPB. (2020b). https://bnpb.go.id/berita/edukasivirus-corona19-badan-nasionalpenanggulangan-bencana.

Permatasari, J., Safitri, D. F., Luthfia, F., \& Orlanda, D. (2019). Penyuluhan PHBS Dalam Mewujudkan Masyarakat Dusun Talang Parit Peduli Akan Kesehatan. 1(1), 18-23.

Raksanagara, A., \& Raksanagara, A. (2016). Perilaku Hidup Bersih Dan Sehat Sebagai Determinan Kesehatan Yang Penting Pada Tatanan Rumah Tangga di Kota Bandung. Jurnal Sistem Kesehatan, 1(1), 30-34. https://doi.org/10.24198/jsk.v1i1.10340

Tirto.id. (2020). Cara Cuci Tangan dengan 7 Langkah Menurut WHO untuk Cegah Corona. Retrieved from https://tirto.id/cara-cucitangan-dengan-7-langkah-menurut-whountuk-cegah-corona-eLyQ

WHO. (2020). Timeline of WHO's response to COVID-19. In https://www.who.int/newsroom/detail/29-06-2020-covidtimeline. 